\title{
Determination of Forage Chemical Composition Using Remote Sensing
}

\author{
Patrick J. Starks, ${ }^{1}$ Samuel W. Coleman, ${ }^{2}$ and William A. Phillips ${ }^{3}$ \\ Authors are ${ }^{1}$ Soil Scientist, USDA-ARS Grazinglands Research Laboratory, El Reno, OK 73036; \\ ${ }^{2}$ Animal Nutritionist, USDA-ARS Subtropical Agricultural Research Station, Brookesville, FL 34601; and \\ ${ }^{3}$ Animal Nutritionist, USDA-ARS Grazinglands Research Laboratory, El Reno, OK 73036.
}

\begin{abstract}
Traditional forage nutrient analysis from bench-top near-infrared spectroscopy (NIRS) or common laboratory chemical procedures provides accurate, point-based information, but often does not provide it in a timely way to allow changes in forage or animal management. The objective of this study is to determine the feasibility of estimating concentrations of nitrogen, neutral detergent fiber (NDF), and acid detergent fiber (ADF) of live, standing forages using a hand-held hyperspectral spectroradiometer (radiometer), and to compare these estimates to values determined via NIRS and laboratory chemical methods. Calibration equations were developed from canopy reflectance measurements from monocultures of Bermuda grass and then applied to a test data set to predict N, NDF, and ADF. Statistical analyses showed that forage composition estimates from the radiometer were equivalent to those from the NIRS. Such a remote-sensing approach would enable real-time assessment of forage quality, would allow mapping of the nutritional landscape, could be used as a tool to better manage pastures and supplements, and would assist in making harvesting decisions.
\end{abstract}

\section{Resumen}

El análisis tradicional de los nutrientes de los forrajes por espectroscopia de infrarrojo cercano (NIRS) o por los procedimientos comunes de análisis de laboratorio proveen información certera como punto de partida, pero a menudo esta información no esta a tiempo para permitir cambios en el manejo del forraje o el animal. El objetivo de este estudio es determinar la factibilidad de estimar las concentraciones de nitrógeno (N), fibra neutro detergente (FND) y fibra ácido detergente (FAD) de forrajes vivos en pie utilizando un espectroradiometro (radiómetro) hiperespectral manual y comparar estas estimaciones con los valores obtenidos vía NIRS y análisis de laboratorio, Las ecuaciones de calibración se desarrollaron a partir de medidas de la reflectancia de la copa de monocultivos de zacate Bermuda y después se aplicaron a un juego de datos de prueba para predecir N, FND y FAD. Los análisis estadísticos mostraron que las estimaciones de la composición del forraje obtenidas con el radiómetro fueron equivalentes a las obtenidas con el NIRS. Esta método de sensores remotos pudiera permitir evaluaciones a tiempo real de la calidad del forraje, permitiría mapear el paisaje nutricional y pudiera ser usado como una herramienta para un mejor manejo de los potreros $y$ suplementos y asistiría en tomar decisiones de cosecha.

Key Words: hyperspectral radiometer, NIRS, nitrogen, neutral detergent fiber, acid detergent fiber

\section{Introduction}

Laboratory assessments of feed and forage quality date back more than 100 years to the proximate analysis system (Kellems and Church 1998; Coleman et al 1999), and more recently to neutral detergent fiber (NDF) and acid detergent fiber (ADF) techniques (Van Soest and Marcus 1964; Van Soest et al 1966; Van Soest and Wine 1968; Van Soest et al 1991). These more recent laboratory chemical procedures are the accepted standards (AOAC 1996) for estimating the nutritive potential of forages, but the results are generally point-based; some of the procedures can produce hazardous laboratory wastes, and the resulting information is often not made available in a timely

Use of company or trade names is strictly for informational purposes and does not imply endorsement by the United States Department of Agriculture to the exclusion of any other product that may be suitable.

Correspondence: Dr Patrick Starks, USDA-ARS, Grazinglands Research Laboratory, 7207 W. Cheyenne St, El Reno, OK 73036. Email: pstarks@grl1.grl.ars.usda.gov

Manuscript received 10 July 2003; manuscript accepted 24 February 2004. fashion to effect changes in feed or livestock management due to the time needed to collect, prepare, and analyze the samples.

Beginning in the mid 1970s, bench-top near-infrared reflectance spectroscopy (NIRS) was evaluated for its potential to provide timely forage quality data comparable to the more traditional chemical procedures (Norris et al 1976). Since then, a large number of studies have been published on the use of NIRS to measure lignin, cell wall carbohydrates, starch, crude protein, dry matter digestibility, and intake among other forage quality variables (eg, Barton and Burdick 1981; Coleman et al 1995; Atanasova et al 1996).

Conventional NIRS evaluation of forage quality necessitates that calibration equations for the forage(s) under consideration be developed (Hruschka 1987). To this end, forage samples are collected from the field, dried, ground to small particle size, and scanned using a bench-top NIRS spectrophotometer. Statistical procedures are then used to develop and quantify relations between the NIR reflectance spectra and forage quality measurements that are determined by chemical procedures.

Determination of standing forage quality via field-based spectroradiometers would further reduce laborious field sampling, and would permit mapping of the nutritional landscape 
Table 1. Number of samples collected, nitrogen fertilizer treatments, hay cutting date, and precipitation received for the Bermuda grass pastures at El Reno, Oklahoma, during 1999, 2000, and 2001.

\begin{tabular}{lrccrrrrr}
\hline & & & \multicolumn{5}{c}{ Rainfall } \\
\cline { 6 - 8 } Year & $n$ & Fertilizer treatment & Hay cut date & April & May & June & July & August \\
\hline & & $\mathrm{kg} / \mathrm{ha}$ & & & $\mathrm{mm}$ & & \\
1999 & 51 & $84,168,336$ & June 28 (DOY' 179) & $125(+45)^{2}$ & $109(-23)$ & $126(+22)$ & $107(+42)$ & $37(-32)$ \\
2000 & 6 & $42,84,168$ & July 1 (DOY 183) & $117(+37)$ & $73(-59)$ & $179(+75)$ & $69(+4)$ & $9(-60)$ \\
2001 & 50 & $52,103,206$ & June 25 (DOY 176) & $11(-69)$ & $181(+49)$ & $28(-76)$ & $24(-41)$ & $86(+17)$ \\
\hline
\end{tabular}

'DOY indicates date of year.

${ }^{2}$ Number in parentheses denotes millimeters of rainfall above or below the 1960-1991, April-August normals.

in near-real time, thereby providing an extra level of information to the farm, ranch, or livestock manager. Although a number of studies have been reported successfully relating canopy-level biochemical properties of nonforage species to remotely sensed data by both hand-held and airborne platforms (eg, Chang and Collins 1983; Wessman et al 1988; Peterson et al 1988; Rock et al 1994; Johnson et al 1994; Yoder and Pettigrew-Crosby 1995; Adams et al 2000), similar studies on forages are limited. Richardson et al (1983) used a hand-held radiometer to estimate $\mathrm{N}$ content of Alicia Bermuda grass, and concluded that remote sensing could be a valuable tool for grazing land management. Selman (1998) collected hand-held spectroradiometer data from mixtures of $\mathrm{C} 3$ and $\mathrm{C} 4$ grasses. Using standard NIRS approaches, Selman (1998) developed calibration equations relating the field reflectance spectra to crude protein (CP), NDF, and ADF. Regression analysis of radiometer-predicted values of $\mathrm{CP}, \mathrm{NDF}$, and $\mathrm{ADF}$ to laboratory reference values yielded moderate $r^{2}$ s of $0.66,0.54$, and 0.42 , respectively, somewhat lower than that normally observed with bench-top NIRS instruments. These moderate $r^{2}$ s may be due to insufficient variation expressed within the data set, because it consisted of only one year's data, or to the mixtures of $\mathrm{C} 3$ and C4 grasses used to develop the calibration equations.

Our objective was to further evaluate whether spectral reflectance data obtained in situ using field remote sensing instruments could be used to predict N, NDF, and ADF. More specifically, we wanted to determine if the $r^{2}$ s could be improved, over that of Selman (1998), by collecting reflectance data from monocultures of a warm-season grass over multiple growing seasons. Bermuda grass was chosen for this study since it is an important forage species used to support the livestock industry over much of the southern Great Plains, south, and southeastern portion of the United States.

\section{Materials and Methods}

\section{Study Site}

The experiment was conducted from April through August of 1999, 2000, and 2001 on 4 pastures (1.6 ha each) containing monocultures of Midland, Midland 99, Worldfeeder, and Ozarka Bermuda grass (Cynodon dacytlon (L.) Pers.). These pastures were located at the Grazinglands Research Laboratory, El Reno, Oklahoma, and were established in 1991 on a Brewer silty clay loam (fine-loamy, mixed, thermic Udic Rhodustalfs). These pastures were managed as part of a different study, but were divided into 6 equal-sized strips receiving 1 of 3 randomly assigned fertilizer treatments (Table 1). Fertility treatments were assumed to foster different growth rates, plant vigor, and nutrient value of the plants, thus providing an ideal experimental site for the project. The pastures were cut for hay once each year during late June or early July (Table 1).

Rainfall was quite variable among the 3 sampling periods compared to the 30-year normals computed for the months of April-August. Rainfall in 1999 was about $10 \%$ above average, near average in 2000 , and about $27 \%$ below average in 2001 (Table 1). Equipment malfunctions and unfavorable meteorological conditions during the 2000 sampling period limited the number of samples that were collected (Table 1).

\section{Field Sampling}

Remotely sensed data and vegetation samples were collected at random times during the early, middle, and late portions of the 1999 sampling period. As noted above, equipment failures during the 2000 sampling period limited the number of remotely sensed measurements that were made, resulting in usable data from only 1 sampling date during this time. Samples were collected weekly in 2001 between day of year (DOY) 115 and 176. The forage was cut for hay on DOY 176 and was not sampled again until DOY 226 and 233.

An SE-590 (Spectron Engineering, Denver, CO) spectroradiometer (hereafter referred to as radiometer) was used to measure solar radiation reflected from the Bermuda grass canopies in 252 wave bands covering the 368-1 100-nm region of the electromagnetic spectrum. The radiometer was mounted on a boom about $2 \mathrm{~m}$ above the soil surface, and had a $6^{\circ}$ fieldof-view, producing a view area with a $21-\mathrm{cm}$ diameter. A single canopy measurement consisted of the average of 3 reflectance measurements made with the radiometer field of view positioned at $90^{\circ}$ to the canopy. The center of each view area was offset from the adjacent one by about $20 \mathrm{~cm}$. Before each canopy measurement, a scan was taken of a reference panel (Labsphere, North Sutton, NH) having a $99 \%$ spectral reflectance factor (over the spectral range of the radiometer). Each canopy measurement was divided by the reference panel reading to produce a reflectance factor (RF), which normalizes the data for variations in incident solar radiation during the sampling period. The RF data were then converted into an "absorbance" spectrum using

$$
\text { absorbance spectrum }=\log _{10}(1 / R F) \text {, }
$$

a mathematical transformation routinely used in development of calibration equations on NIRS systems (Hruschka 1987).

A $0.5 \mathrm{~m}^{2}$ vegetation sampling frame was placed around the area viewed by the radiometer, and all vegetation within the 


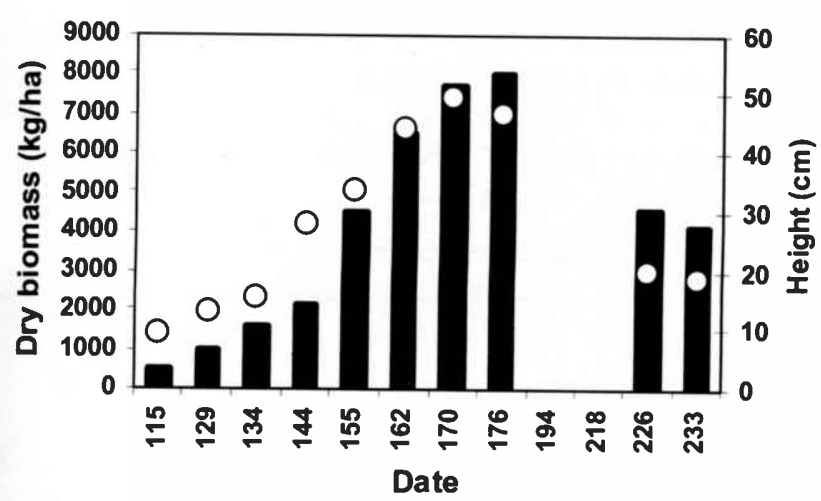

Biomass o Height

Figure 1. Average weekly biomass (dry matter basis) and height of forage observed during the 2001 study period. Average values from 1999 and 2000 fell within the range observed for 2001.

frame was clipped to ground level, bagged, and dried for 48 hours at $65^{\circ} \mathrm{C}$ in a forced-air oven. About one-half of the dried sample was then ground to pass a $2-\mathrm{mm}$ screen using a Wiley laboratory mill, and then ground through a $1-\mathrm{mm}$ screen in a cyclone mill (Udy Corporation, Fort Collins, CO).

\section{Laboratory Measurements}

A portion of each ground sample was used for determination of laboratory concentrations of N, NDF, and ADF. NDF and ADF were determined according to the protocol outlined on Ankom Technology's (Fairport, NY) Web site (http://www. ankom.com/faqs/index.html). Nitrogen content was determined using an automated total combustion instrument (Leco, St. Joseph, MN).

Another portion of each ground sample was packed into a circular sample cup with a $2.5-\mathrm{cm}$ glass cover, and scanned with a bench-top NIRS system (Model 6500, FOSS-NIRSystems, Silver Spring, MD) from 400 to $2500 \mathrm{~nm}$, but only the data in the 400-1 100-nm region were used in this study because this region closely matched that measured by the radiometer. During scanning, computer software automatically measures reflectance from an internal reference standard and then calculates, according to Equation 1, the absorbance spectra of the sample.

\section{Equation Development/Cross-Validation and Testing}

Of 107 samples in the data set, 77 were randomly selected to develop/cross-validate the calibration equations, while the remaining 30 samples were used as a test data set to validate the equations.

Development and validation of equations was performed separately for the radiometer and NIRS approaches using WINISI software (Infrasoft, 1999). The spectra from each instrument were subjected to identical mathematical treatments to facilitate direct comparison between the bench-top NIRS and radiometer approaches. Modified partial least-squares regression (Goedhart 1990; Shenk and Westerhaus 1991) was used, but was preceded by standard normal variate (SNV) scatter correction, detrending, and a 1,4,4,1 math treatment (first derivative, gap over which the derivative is calculated, number

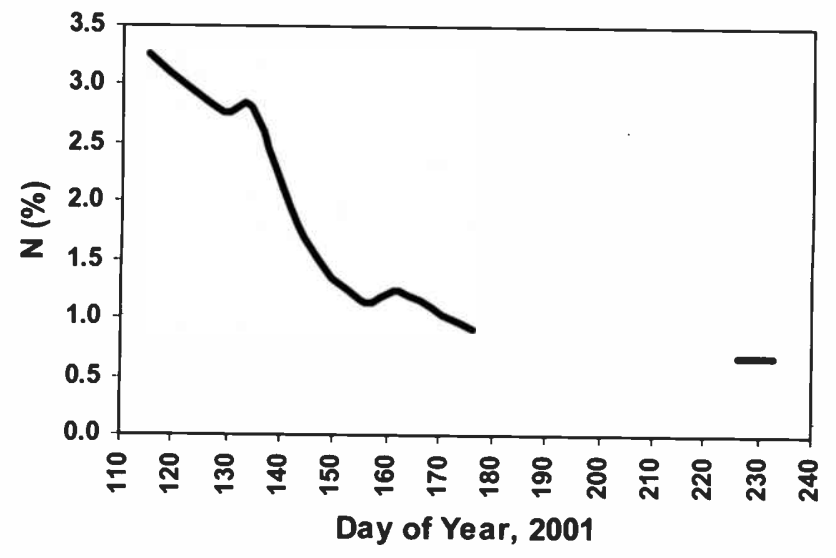

Figure 2. Time series of average weekly percent $\mathrm{N}$ observed during the 2001 study period. Average values from 1999 and 2000 fell within the range observed for 2001.

of points used in the first smoothing, and no second smoothing). The SNV treatment scales each spectrum so that it has a standard deviation of 1.0 , which helps reduce particle size effects (Barnes et al 1989; Baker and Barnes 1990). This option was chosen because spectra from the radiometer were obtained from a canopy, whereas the spectra from the NIRS were derived from finely ground samples. Detrending helps remove linear and quadratic curvature of each spectrum (Barnes et al 1989).

Statistics reported for the equation development/cross-validation phase include the standard error of the calibration (SEC), $r^{2}$, standard error of the cross validation (SECV), and variance ratio remainder (1-VR). Statistics reported for the calibration equation test data set include the mean $(\bar{x})$, standard deviation $(s)$, standard error of the prediction (SEP), $r^{2}$, slope, and bias.

\section{Results}

\section{Forage Characteristics}

In the 2001 study period, average weekly biomass values ranged from about $500 \mathrm{~kg} \mathrm{ha}^{-1}$ (dry matter basis) on DOY 115 to about $8000 \mathrm{~kg} \mathrm{ha}^{-1}$ on DOY 176 (Fig. 1). Correspondingly, forage height ranged from a minimum of 9 to 47 $\mathrm{cm}$ on these days (Fig. 1). Biomass and forage height values

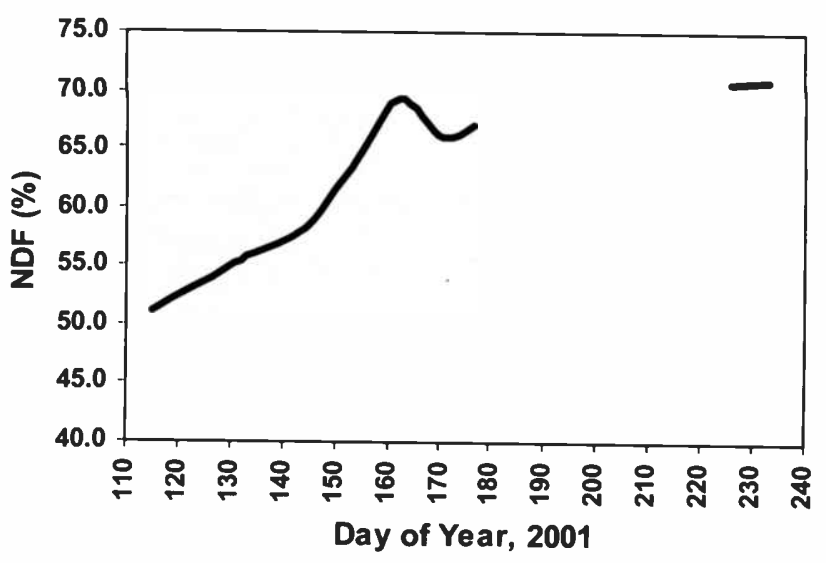

Figure 3. Time series of average weekly percent neutral detergent fiber observed during the 2001 study period. Average values from 1999 and 2000 fell within the range observed for 2001. 


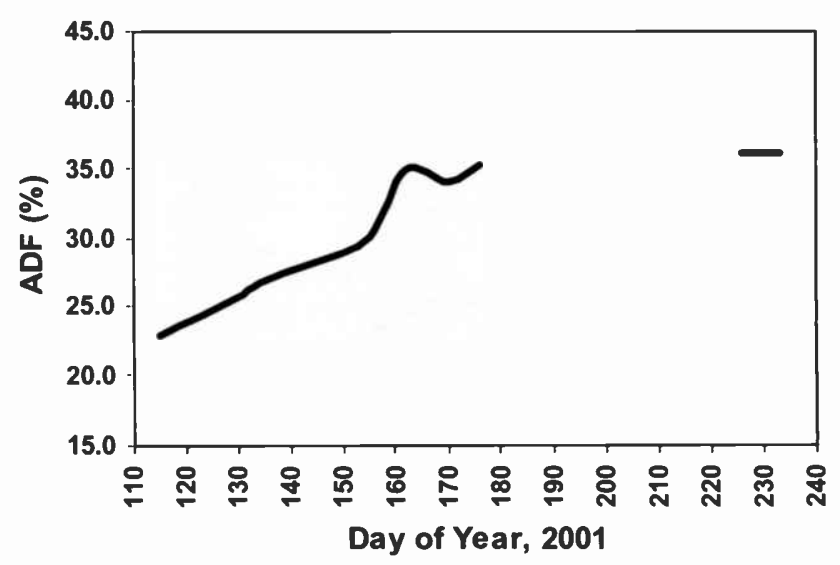

Figure 4. Time series of average weekly percent acid detergent fiber observed during the 2001 study period. Average values from 1999 and 2000 fell within the range observed for 2001.

from the 1999 and 2000 study periods fell within the range observed for the 2001 data set. Average weekly values of $\% \mathrm{~N}$ for the 2001 study period (Fig. 2) ranged from a high of 3.3 on DOY 115 to a low of about 0.7 on DOY 233. The 2001 data set shows $\% \mathrm{~N}$ decreasing at a rate of about $0.05 \%$ day $^{-1}$ over the first 39 days of the study period (DOY 115 to 155), then decreasing at a slower rate $\left(0.01 \% \mathrm{day}^{-1}\right)$ over the remainder of the study period. Average weekly NDF increased from about $50 \%$ to $70 \%$ over the 2001 study period (Fig. 3), while ADF increased from about $23 \%$ to $36 \%$ (Fig. 4). Values of N, NDF, and ADF from the 1999 and 2000 data sets fell within the ranges observed for the 2001 data set.

\section{Calibration/Cross-Validation Data Set}

Calibration and cross-validation statistics (Table 2) indicate that the spectral data from the bench-top NIRS produced estimates of N, NDF, and ADF in closer agreement with the laboratory reference values than estimates generated using the radiometer spectral data. The radiometer SECs were higher than those observed for the NIRS for all 3 forage variables. The radiometer SEC for $\mathrm{N}$ was about $50 \%$ higher than that of the NIRS, but for NDF and ADF was within $10 \%$ of the SECs from the NIRS. The

Table 2. Statistics from the calibration equation development and cross-validation phase for the near-infrared spectroscopy (NIRS) and radiometer data sets $(n=77)$.

\begin{tabular}{lcccc}
\hline System & $\begin{array}{c}\text { SEC' } \\
\%\end{array}$ & $r^{2}$ & $\begin{array}{c}\text { SEC(V) } \\
\%\end{array}$ & 1-VR \\
\hline NIRS & \multicolumn{5}{c}{$\mathrm{N}$} & & \\
Radiometer & 0.14 & 0.96 & 0.24 & 0.88 \\
& 0.30 & 0.82 & 0.42 & 0.64 \\
NIRS & & NDF & & \\
Radiometer & 2.15 & 0.84 & 2.63 & 0.77 \\
& 2.36 & 0.77 & 3.01 & 0.62 \\
NIRS & & ADF & & \\
Radiometer & 1.21 & 0.90 & 1.76 & 0.80 \\
\hline
\end{tabular}

'SEC indicates standard error of the calibration; $\operatorname{SEC}(\mathrm{V})$, standard error of the cross-validation; $1-V R$, variance ratio remainder; NDF, neutral detergent fiber; ADF, acid detergent fiber.
Table 3. Statistical results of near-infrared spectroscopy (NIRS) and radiometer calibration equations applied to the test data set $(n=30)$; mean and standard deviations are also presented for laboratory reference values as well as for NIRS and radiometer approaches.

\begin{tabular}{lcccr}
\hline & $\bar{x}$ & $s$ & SEP1 & bias \\
\cline { 2 - 5 } System & \multicolumn{5}{c}{$\%$} \\
\hline Laboratory & 1.5 & 0.62 & & \\
NIRS & 1.5 & 0.66 & 0.27 & 0.03 \\
Radiometer & 1.6 & 0.61 & 0.32 & -0.06 \\
& & NDF & & \\
Laboratory & 65.2 & 4.38 & & -0.28 \\
NIRS & 65.1 & 4.17 & 2.40 & 0.41 \\
Radiometer & 64.8 & 3.93 & 2.73 & \\
& & ADF & & -0.39 \\
Laboratory & 32.9 & 3.66 & & -0.19 \\
NIRS & 33.3 & 3.42 & 1.69 & \\
Radiometer & 33.1 & 3.09 & 2.06 & \\
\hline
\end{tabular}

'SEP indicates standard error of the prediction; ADF, acid detergent fiber; NDF, neutral detergent fiber.

radiometer $r^{2}$ s were all lower than their NIRS counterparts, but the spectral information from the radiometer approach accounted for $77 \%$ to $85 \%$ of the variability in the laboratory reference values, depending upon the forage variable.

Cross-validation statistics of SECV and 1-VR were customarily higher and lower, respectively, than their SEC and $r^{2}$ counterparts (Table 2). The largest relative differences between SEC and SECV were observed for the NIRS N (about 40\%) and radiometer $\mathrm{ADF}$ (about $37 \%$ ). From the 1-VR statistic, it is observed that the NIRS approach accounted for about $15 \%$ to $24 \%$ more of the variation in the laboratory data than the radiometer approach. However, the radiometer approach accounted for $60 \%$ to $64 \%$ of the variation in the laboratory reference data.

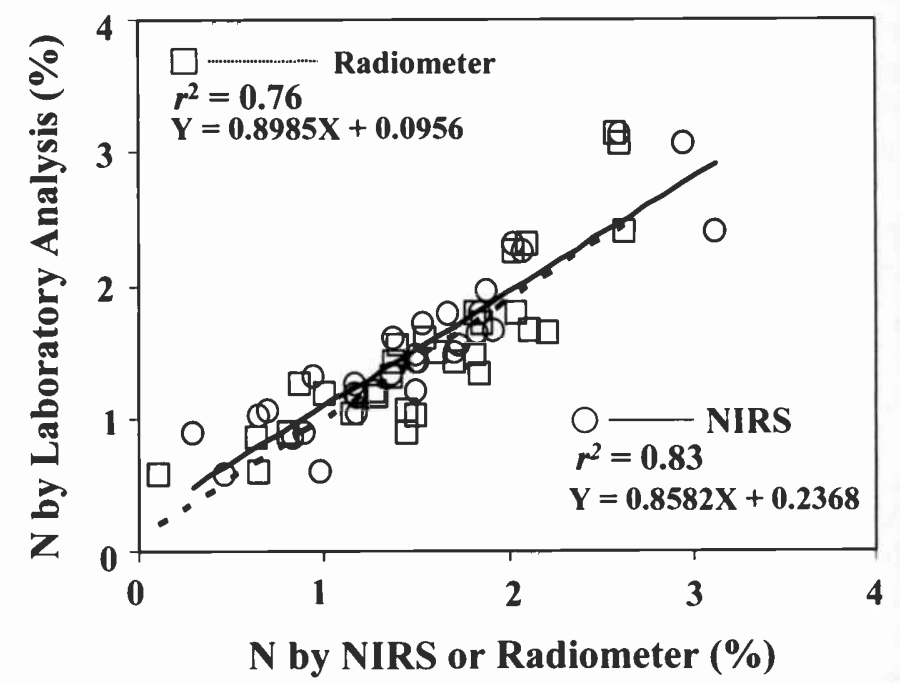

Figure 5. Scatterplot of predicted percent $\mathrm{N}$ values from the nearinfrared spectroscopy or radiometer vs that measured in the laboratory $(n=30)$. 


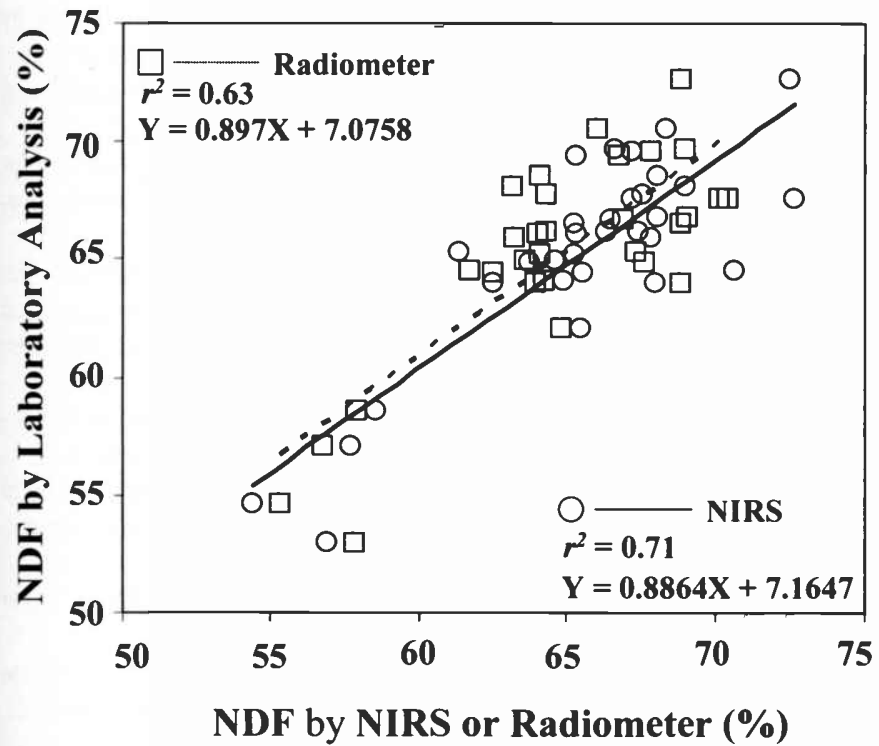

Figure 6. Scatterplot of predicted percent neutral detergent fiber values from the near-infrared spectroscopy or radiometer vs that measured in the laboratory $(n=30)$.

\section{Test Data Set}

Predicted forage composition values derived from application of the NIRS and radiometer calibration equations to the test data sets were statistically compared to laboratory reference values. It is observed (Table 3) that mean values and standard deviations derived from the NIRS and radiometer approaches are comparable to the laboratory reference values (ie, low bias). SEPs from the radiometer were from $13 \%$ to $16 \%$ larger than that of the NIRS. However, Bartlett's test showed that there was no statistical difference between the NIRS and radiometer

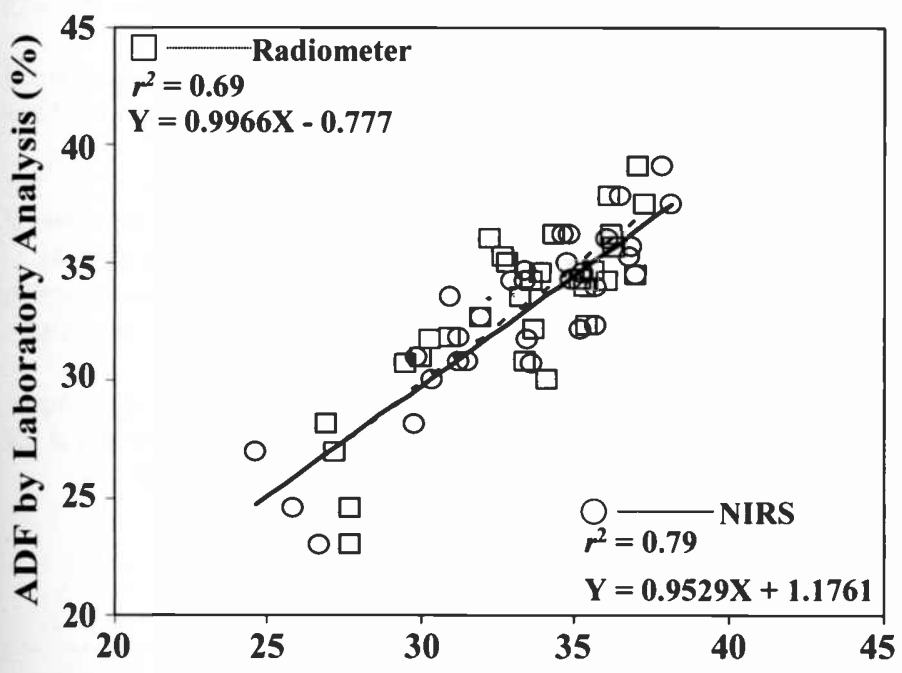

\section{ADF by NIRS or Radiometer (\%)}

Figure 7. Scatterplot of predicted percent acid detergent fiber values from the near-infrared spectroscopy or radiometer vs that measured in the laboratory $(n=30)$.
Table 4. Slope terms after fitting regression equations with a zerointercept.

\begin{tabular}{lll}
\hline System & N & Slope \\
\hline & & \\
NIRS & NDF & 0.99 \\
Radiometer & 0.952 \\
& & \\
NIRS & & 0.995 \\
Radiometer & ADF & 1.006 \\
& & \\
NIRS & & 0.998 \\
Radiometer & & 0.994 \\
\hline
\end{tabular}

SEPs $(0.12 \geq P \leq 0.5)$. Regression analysis revealed that the NIRS $r^{2}$ values were all larger than their counterparts derived from the radiometer data (Figs. 5-7), and that both the NIRS and radiometer $r^{2}$ values from the test data set were lower than those observed in the calibration data set (Table 2). Nevertheless, the radiometer spectral data accounted for $63 \%$ to $76 \%$ of the variability in the laboratory reference data. Covariance analysis indicated that, for a given forage variable, there was no statistical difference between the NIRS and radiometer slopes $(P \geq 0.72)$ and that there was no need to fit an intercept term in the regressions. Thus, the general linear models relating the NIRS and radiometer predictions to laboratory reference values were rerun forcing the regressions through the origin. This reanalysis resulted in slope values much nearer one (Table 4) for both approaches.

\section{Discussion}

For this study, it was shown that calibration equations could be developed from reflectance data collected from live standing Bermuda grass canopies to predict N, NDF, and ADF. Moreover, it was observed that these predictions were comparable to those made using laboratory NIRS analysis of clipped, dried, and ground forage samples.

Although the study findings indicated that the remote sensing approach accounted for most of the variability in the laboratory reference values, less precision could be expected from this approach for at least 2 reasons. First, the sample of ground forage scanned by the NIRS instrument is very similar to that used to conduct reference chemistry for percent N, NDF, and ADF, whereas the radiometer approach measures reflectance of the forage before it is harvested. Sampling could be a significant factor in the difference between the precision of the 2 approaches. Second, the NIRS approach measures reflectance under controlled lighting conditions, but the radiometer approach measures reflectance from a live canopy under variable lighting conditions. Canopy characteristics, especially those with diverse plant populations, could contribute to variability as well. It should also be noted that, under the experimental conditions in this study, the Bermuda grass canopies were closed, minimizing any effects due to soil reflectances. In more open canopies, soil effects will have to be taken into account. 
Findings from the study suggest that, for Bermuda grass, accurate remotely sensed estimates of forage composition can be obtained on standing forage from hyperspectral reflectance data. Additional warm and cool season forages will need to be studied to demonstrate the general utility of the remote sensing approach. Further testing to determine the applicability of this approach to predicting digestibility and intake is needed. If successful, this approach would allow landscape-scale nutritional information to be coupled with estimates of forage quantity, providing timely forage status assessments to the rancher, animal manager, and hay producer. Ultimately, this technology would improve profit margins by enabling timely decisions by producers of forage and animal resources. Currently, studies are under way evaluating the efficacy of this remote sensing approach to make decisions regarding the need for and timing of supplemental feeds in a Bermuda grass-based grazing system in Oklahoma.

\section{Acknowledgments}

We thank John Ross and Dale Pardue for their help in collecting and processing both the spectral and vegetation data. We also thank Mike Brown for providing assistance with the statistical analysis.

\section{Literature Cited}

Adams, M. L., W. A. Norvell, W. D. Philpot, and J. H. Peverly. 2000. Spectral detection of micronutrient deficiency in 'Bragg' soybean. Agronomy Journal 92: 261-268.

Antanasova, S., N. Todorov, and D. Pavlov. 1996. Estimation of dry matter and crude protein degradability of forages in the rumen by NIRS. In: Batten et al [eds.]. Leaping ahead with near infrared spectroscopy. North Melbourne, Victoria, Australia: NIR Spectros. Group. p 497-501.

AOAC. 1996. Official methods of analysis. 14th ed. Washington, DC: Associaton of Official Analytical Chemists.

BaKeR, C. W., AND R. BARneS. 1990. The application of near infrared spectrometry to forage evaluation in the agricultural development and advisory service. $\mathrm{In}$ : J. Wiseman and D. J. A. Cole [eds.]. Feedstuff evaluation. London, UK: Butterworth's. p 337-351.

Barnes, R. J., M. S. DhanoA, and S. J. Lister. 1989. Standard normal variate transformation and de-trending of near-infrared diffuse reflectance spectra. Applied Spectroscopy 43:772-777.

Barton F. E. II, AND D. BuRdick. 1981. Prediction of forage quality with NIR reflectance spectroscopy. In: Smith and Hays [eds.]. Proceedings of the XVI International Grasslands Congress; Lexington, KY. p 532-534.

Chang, S. C., and W. Coluins. 1983. Confirmation of the airborne biogephysical mineral exploration technique using laboratory methods. Economic Geology 78:723-736.

Coleman, S. W., H. Lippke, and M. GltL. 1999. Estimating the nutritive potential of forages. In: Jung and Fahey [eds.]. Nutritional ecology of herbivores. Proceeding of the Vth International Symposium on the Nutrition of Herbivores; San Antonio, TX. American Society for Animal Science, Savoy, IL. p 647-695.
Coleman, S. W., J. W. Stuth, and J. W. Holloway. 1995. Prediction of intake by near-infrared spectroscopy analysis of fecal samples. In: Owens et al. [eds.]. Symposium: Intake by Feedlot Cattle; Oklahoma Agricultural Experiment Station P-942, Stillwater, OK. p 145-155.

GoEDHART, P. W. 1990. Comparison of multivariate calibration methods for prediction of feeding value by near infrared reflectance spectroscopy. Netherlands Journal of Agricultural Science 38:449-460.

HruschKA, W. R. 1987. Data analysis: Wavelength selection methods. In: Williams and Norris [eds.]. Near-infrared technology in the agricultural and food industries. St. Paul, MN: American Association of Cereal Chemists. p 35-55.

INFRASOFt INTERNATIONAL. 1999. ISI WINDOWS Near-Infrared Software, WinISI II Version 1.02A, FOSS NIRSystems/TECATOR, Infrasoft International, LLC.

Johnson, L. F., C. A. HlavkA, and D. L. Peterson. 1994. Multivariate analysis of AVIRIS data for canopy biochemical estimation along the Oregon transect. Remote Sensing of the Environment 47:216-230.

Kellems, R. O., and D. C. Сhurch. 1998. Livestock feeds and feeding. 4th ed. Upper Saddle River, NJ: Prentice Hall. p 59-84.

Norris, K. H., R. F. Barnes, J. E. Moore, and J. S. Shenk. 1976. Predicting forage quality by infrared reflectance spectroscopy. Journal of Animal Science 43 889-897.

Peterson, D. L., J. D. Aber, P. U. C. Matson, D. H. Card, N. Swanberg, C. Wessman, and M. Spanner. 1988. Remote sensing of forest canopy and leaf biochemical contents. Remote Sensing of the Environment 24:85-108.

Richardson, A. J., J. H. Everitr, and H. W. Gausman. 1983. Radiometric estimation of biomass and nitrogen content of Alicia grass. Remote Sensing of the Environment 13:179-184.

Rock, B. N., D. L. Williams, D. M. Moss, G. N. Lauten, and M. Kim. 1994. Highspectral resolution field and laboratory optical reflectance measurements of Red Spruce and Eastern Hemlock needles and branches. Remote Sensing of the Environment 47:176-189.

SeLman, S. L. 1998. Field radiometry for analysis of forages and pasture quality [Master's thesis]. Brookings, SD: South Dakota State University. p 92.

Shenk, J. S., and M. O. Westerhaus. 1991. Population definition, sample selection, and calibration procedures for near infrared reflectance spectroscopy. Crop Science 31:469-474.

Van Soest, P. J., and W. C. Marcus. 1964. Method for the determination of cell wall constituents in forages using detergent and the relationship between this fraction and voluntary intake and digestibility. Journal of Dairy Science 47:704.

Van Soest, P. J., J. B. Robertson, and B. A. Lewis. 1991. Methods of dietary fiber, neutral detergent fiber, and nonstarch polysaccharides in relation to animal nutrition. Journal of Dairy Science 74:3583-3597.

VAN Soest, P. J., AND R. H. Wine. 1968. Determination of lignin and cellulose in acid detergent fiber with permanganate. Journal of the Association of Official Agricultural Chemists 51:780.

Van Soest, P. J., R. J. Wine, and L. A. Moore. 1966. Estimation of the true digestibility of forage by the in vitro digestion of cell walls. $n$ : Proceedings of the 10th International Grasslands Congress; Helsinki, Finland. p 438-441.

Wessman, C. A., J. D. Aber, D. L. Peterson, and J. M. Melillo. 1988. Remote sensing of canopy chemistry and nitrogen cycling in temperate forest ecosystems. Nature 335:154-156.

Yoder, B. J. and R. E. Pettigrew-Crosby. 1995. Predicting nitrogen and chlorophyll content and concentrations from reflectance spectra $(400-2500 \mathrm{~nm})$ at leal and canopy scales. Remote Sensing of the Environment 53:199-211. 